\title{
TECTÔNICA E SEDIMENTAÇÃO NA BACIA DO CAMAQUÃ CENTRAL (RS): EXEMPLOS DO GRUPO GUARITAS E DO GRUPO SANTA BÁRBARA
}

\section{Maurício Guerreiro Martinho dos Santos}

Orientador: Prof. Dr. Renato Paes de Almeida

DISSERTAÇÃO DE MESTRADO

Programa de Pós-Graduação em Geoquímica e Geotectônica

SÃO PAULO

2010 



\section{ÍNDICE}

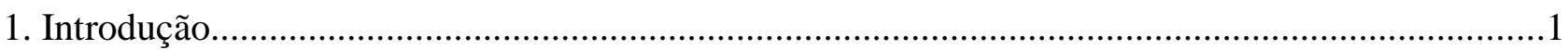

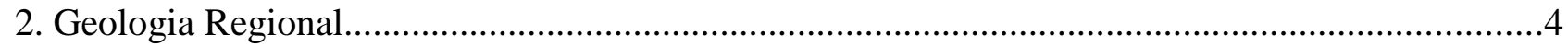

2.1. Evolução dos conhecimentos sobre a Bacia do Camaquã........................................................

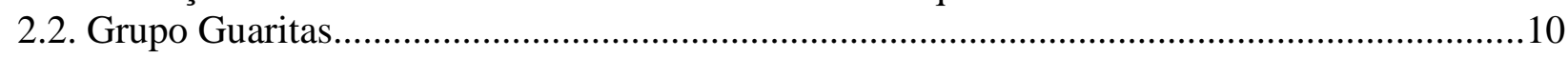

2.3. Grupo Santa Bárbara na Região das Minas do Camaquã......................................................17

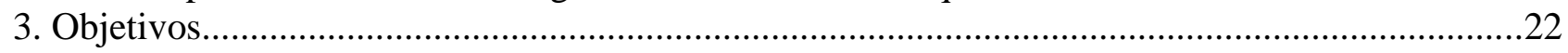

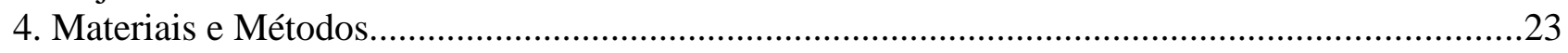

4.1. Análise de Elementos Arquiteturais..................................................................................2

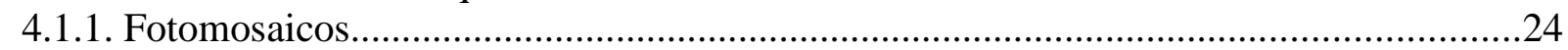

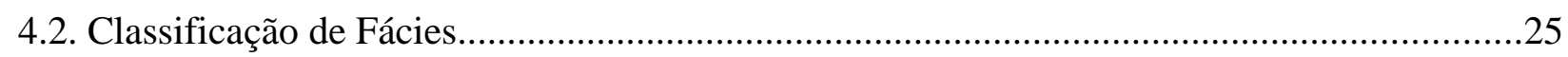

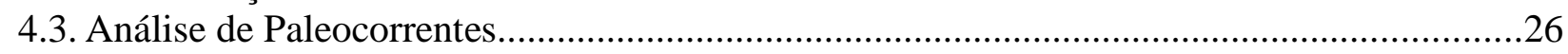

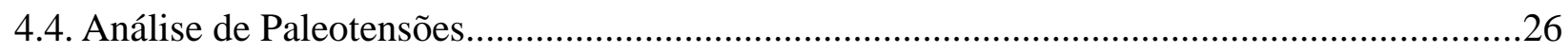

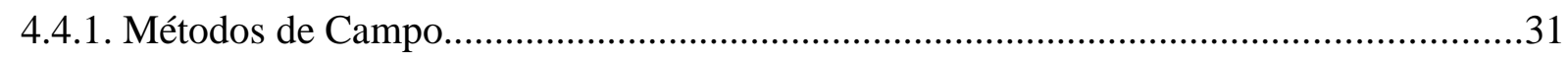

4.4.2. Métodos de análise estrutural e correlação cronológica.....................................................31

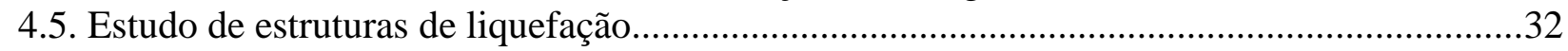

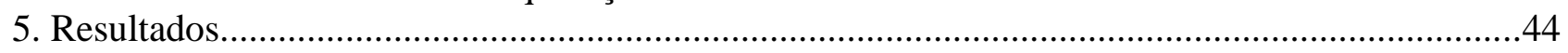

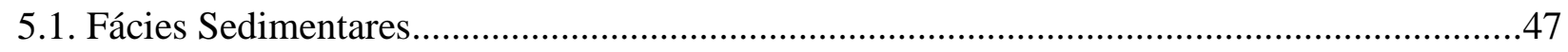

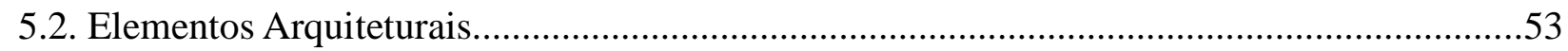

5.3. Descrição dos afloramentos e fotomosaicos mais relevantes................................................57

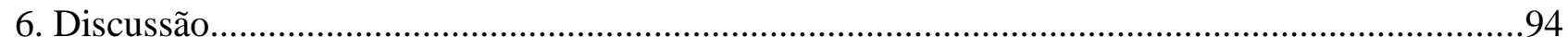

6.1. Análise de Fácies Sedimentares e Elementos Arquiteturais...................................................94

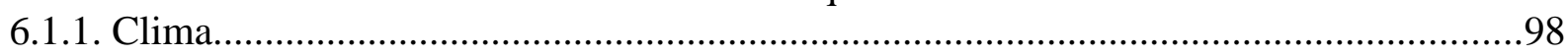

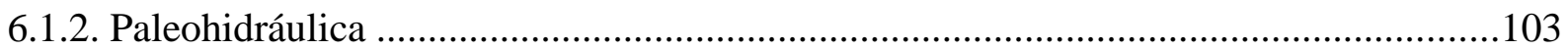

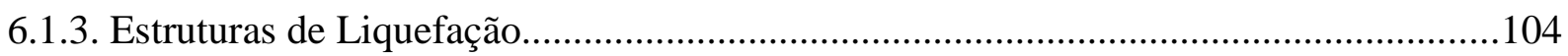

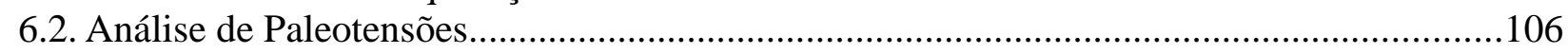

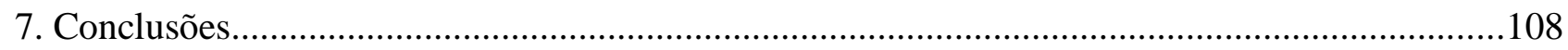

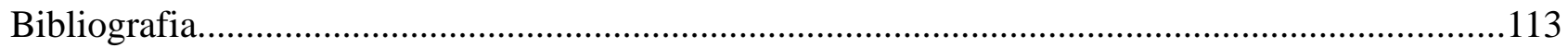





\section{Introdução}

As relações entre atividade tectônica e características de sistemas deposicionais em bacias tectonicamente ativas incluem diversos aspectos, desde padrões de empilhamento estratigráfico de grande escala (e.g. Blair \& Bilodeau 1988) e variações na proveniência dos depósitos, até aspectos como a granulação (e.g. Marr et al. 2000, Paola 1988, Paola et al. 1992) e proporção de preservação de planícies aluviais em sistemas fluviais (e.g. Wright \& Marriot 1993, Shanley \& McCabe 1994). O presente trabalho aborda dois aspectos complementares das relações entre tectônica e sedimentação em depósitos da Bacia do Camaquã (Ediacarano-Eocambriano, RS): a caracterização dos paleocampos de tensão e da cronologia dos eventos de deformação rúptil reconhecidos na bacia, e o detalhamento da arquitetura de depósitos fluviais sin-tectônicos de uma sucessão aluvial rica em evidências de atividade sísmica penecontemporânea.

Dessa forma, foram realizados estudos detalhados de arquitetura deposicional de exposições da Formação Guarda Velha na região das Minas do Camaquã, que resultaram em reconstituições da características desse sistema deposicional, considerando-se a influência da tectônica sin-deposicional e de fatores climáticos.

A cronologia e as paleotensões dos eventos de deformação rúptil foram investigados para se reconhecer as características do regime de esforços responsável pela origem da bacia, de forma a se integrar os dados de arquitetura deposicional da Formação Guarda Velha a um modelo bacinal coerente, considerando-se a divergência entre diferentes autores sobre a classificação da bacia (se de antepaís, transcorrente ou distensional tipo rift). Para tanto, foram adquiridos novos dados, que, integrados a dados preexistentes (que foram reprocessados), resultaram em uma revisão da cronologia de eventos de deformação para toda 
a bacia (Anexo 1), além de uma caracterização dos eventos que afetaram de forma mais expressiva a região das Minas do Camaquã (Anexo 2).

A Bacia do Camaquã registra importantes eventos de tectônica e sedimentação a partir do Ediacarano. As rochas agrupadas por Fragoso-Cesar et al. (2003) no Supergrupo Camaquã foram depositadas em sistemas de rift intra-continentais de idade ediacarana a eocambriana (Almeida et al. 2010) e posteriormente submetidas a diversos eventos tectônicos de deformação. Caracterizaremos aqui o ambiente deposicional de uma unidade estratigráfica em particular bem como a história tectônica do Supergrupo Camaquã.

Durante o Eocambriano, estabeleceu-se na região um regime de esforços distensivo responsável pelo rift Guaritas, caracterizado por uma calha sobre na qual foi estabelecido ou mesmo capturado um imponente sistema fluvial caracterizado a seguir. Este sistema bacinal foi decorrente de pulsos de subsidência com distensão NW-SE (Almeida et al. 2009) em ambiente continental de clima semi-árido a árido (Fragoso-Cesar et al. 1984, Lavina et al. 1985, De Ros et al. 1994) com espessas sucessões siliciclásticas de sistemas fluviais de estilo entrelaçado (e.g. Fragoso-Cesar et al. 1984, Lavina et al. 1985, Paim 1994, Almeida 2005). O estudo aqui apresentado da arquitetura deposicional dos sistemas fluviais da Formação Guarda Velha, unidade basal do Grupo Guaritas, foi desenvolvido principalmente na região da Serra das Guaritas, onde ocorrem afloramentos representativos da unidade expostos em escarpas de morrotes. Estudos comparativos foram realizados também nas localidades do Passo do Cação e Rincão da Guarda Velha, este a seção tipo da unidade litoestratigráfica em questão. Foi realizado um estudo de detalhe de afloramentos escolhidos criteriosamente para a confecção de painéis e fotomosaicos necessários à caracterização de elementos arquiteturais, através de seções estratigráficas levantadas em alta densidade nas exposições estudadas, análise de fácies sedimentares e realização de croquis. São discutidas estruturas de deformação sin-sedimentares de reologia dúctil definidas como de origem alocinética por 
diversos trabalhos baseados tanto em rochas de diferentes unidades geológicas de distintas regiões ao redor do mundo como a partir de experiências em laboratórios relatadas na literatura. Estas estruturas são investigadas como representantes da atividade tectônica sinsedimentar e correlacionadas às informações de fácies sedimentares e arquitetura deposicional encontradas para caracterização do ambiente deposicional.

As estruturas rúpteis geradas pelo evento responsável pela deposição do Grupo Guaritas são encontradas em diversas regiões da Bacia e aqui são apresentadas em anexo no trabalho Almeida et al. (inédito). As estruturas relativas às atividades tectônicas posteriores à deposição da Formação Guarda Velha são abordadas através de análises de paleotensões em falhas com estrias e indicadores cinemáticos obtidos em área próxima da região das Guaritas, nas cavas das Minas do Camaquã, e incluídos no artigo anexo Santos et al. (submetido à Revista Brasileira de Goeciências). Ambos artigos seguem parâmetros internacionais adotados pelo World Stress Map. 


\section{Geologia Regional}

Durante o Neoproterozóico, desenvolveram-se na região do Alto Estrutural do Rio Grande, centro-sul do atual Estado do Rio Grande do Sul, rifts intracontinentais relacionados regionalmente a um sistema maior de bacias, nomeadas Bacias do Estágio de Transição (prancha 1A) por Almeida (1969). Este autor considerou o período como de estabilização tectônica após a Orogenia Brasiliano-Pan-Africana, responsável pela formação do Gondwana Ocidental. Essa orogenia foi registrada no cinturão metamórfico Dom Feliciano e no Terreno Rio Vacacaí (Fragoso-Cesar 1991). Trabalhos recentes propõem um ambiente distensional já sem relação com a orogenia (e.g. Fragoso-Cesar et al. 2003, Almeida et al. 2010).

No Rio Grande do Sul, sobre o embasamento metamórfico brasiliano desenvolveramse depósitos vulcano-sedimentares de idade ediacarana a eocambriana, que foram agrupados no Supergrupo Camaquã (prancha 1B), por Fragoso-Cesar et al. (2003). Este é composto, da base para o topo, pelo Grupo Maricá (depósitos siliciclásticos marinhos e fluviais), Grupo Bom Jardim (depósitos aluviais e lacustres além de vulcânicas intermediárias a básicas), Formação Acampamento Velho (vulcânicas ácidas e básicas), Grupo Santa Bárbara (depósitos aluviais e costeiros), Grupo Guaritas (depósitos aluviais e eólicos) e Suíte Intrusiva Rodeio Velho (subvulcânicas básicas a intermediárias), esta última datada em 535 Ma (Almeida 2005, Almeida et al. 2010). O preenchimento da bacia totaliza mais de 10.000 metros de espessura (Almeida 2005) e suas ocorrências são controladas por falhas de direção NNE, sendo adotada uma subdivisão em três sub-bacias separadas por falhas de alto ângulo que delimitam os altos de Caçapava do Sul e da Serra das Encantadas: as sub-bacias Camaquã Ocidental, Central e Oriental.

Segundo Almeida (2005), o Grupo Santa Bárbara aflora nas três sub-bacias, com 
PRANCHA 01 

ocorrências contínuas nas sub-bacias Camaquã Ocidental e Oriental, e em janelas estruturais sob o Grupo Guaritas na Sub-Bacia Camaquã Central. Na Sub-Bacia Camaquã Central, onde se encontra a ocorrência ora estudada, aparecem depósitos conglomeráticos de leques aluviais, arenitos e conglomerados fluviais de rios entrelaçados e arenitos e ritmitos de sistemas fluviais efêmeros distais e de sistemas lacustres.

O Grupo Guaritas, separado do Grupo Santa Bárbara por discordância angular, apresenta mais de $1500 \mathrm{~m}$ de espessura de sedimentos aluviais e eólicos, sendo subdividido nas seguintes unidades, da base para o topo (Almeida 2005): Formação Guarda Velha e Formação Varzinha (Camadas Guarda Velha e Camadas Varzinha, Ribeiro 1970, Ribeiro \& Lichtemberg, 1978), Formação Pedra Pintada (Arenitos Pedra Pintada, Fragoso-Cesar 1991), Formação Pedra das Torrinhas (Ruditos Pedras das Torrinhas, Fragoso-Cesar 1991) e Formação Serra do Apertado (Almeida, 2005). Registra sistemas fluviais efêmeros, além de importantes depósitos eólicos e de leques aluviais, compostos por arenitos e conglomerados.

\subsection{Evolução dos conhecimentos sobre a Bacia do Camaquã}

Carvalho (1932) nomeou as rochas da região das minas como "Série Camaquã", embora sem denominar sua localidade-tipo, seguindo os estudos do Dr. Eusébio de Oliveira, que descreveu as rochas da região. Correlacionou essas rochas ao Eopaleozóico, notando que são posteriores aos andesitos da região e anteriores ao Permiano. Descreveu os sedimentos como bastante movimentados e ondulados e em discordância com os do Permiano. Reconheceu o caráter regional, sedimentar, a atividade tectônica intensa e o vulcanismo associado. Posteriormente Leinz et al. (1941) adicionaram uma nova unidade anterior à série, caracterizada por forte inclinação e definida como Formação Maricá. Robertson (1966) definiu o Grupo Camaquã, subdividido em Formações Santa Bárbara e Guaritas, posteriores à Formação Maricá e ao Andesito Hilário. Fragoso-Cesar et al. $(1984,1985)$ reuniram todas essas unidades no Grupo Camaquã. Várias interpretações sobre o estilo tectônico e de 
preenchimento desta bacia já foram propostas. Fragoso-Cesar (1991) propõe que a Bacia do Camaquã seria o correlato bacinal da terceira e última orogenia que originou o Cinturão Dom Feliciano. Foi considerada a hipótese de uma bacia molássica relacionada à Orogenia Brasiliana (Fragoso-Cesar et al. 1985, Fragoso-Cesar 1991). Posteriormente foram propostos modelos de bacias transcorrentes de fases tardias do evento colisional (Oliveira \& Fernandes 1991, 1992, Machado \& Sayeg 1992) e finalmente foram caracterizadas como bacias distensionais tipo rift sem vínculo com a orogênese (Fragoso-Cesar et al. 2000ª 2000 ${ }^{\mathrm{b}}, 2001$, Almeida 2005, Almeida et al. 2010).

Fragoso Cesar et al. (1985) definiram a Antefossa Camaquã, que caracterizaram como ocorrências sedimentares limitadas entre o Cinturão Dom Feliciano e o Cráton Rio de La Plata. Fragoso Cesar (1991) restringiu o conceito de Grupo Camaquã apenas para as unidades da Antefossa Camaquã, composta pela Formação Arroio dos Nobres de Tessari \& Picada (1966) e pela Formação Guaritas de Robertson (1966). Fragoso-Cesar (1991) definiu a Molassa Guaritas, constituída por cinco sub-unidades: Ruditos Pedra das Torrinhas, Arenitos Guarda Velha, Arenitos Pedra Pintada, Ritmitos Varzinha e Andesitos Rodeio Velho. Apontou os Arenitos Guarda Velha como litofácies mais importante da Molassa Guaritas, associados vertical e lateralmente com as demais. Interpretou os espessos pacotes conglomeráticos como produto de superposição de barras longitudinais; os arenitos de estratificação acanalada foram interpretados como decorrentes da ação de dunas sub-aquosas; os arenitos tabulares, indicativos de migração de barras transversais. Enfatizou ainda a ocorrência restrita de níveis pelíticos. A proveniência dos Arenitos Guarda Velha é definida por aquele autor como rochas de terrenos metamórficos, destacando a predominância de rochas miloníticas da Serra das Encantadas, além de granitos possivelmente oriundos do Cinturão Dom Feliciano.

Paim (1994) e Paim et al. (1995, 2000) utilizaram-se dos conceitos de estratigrafia de sequências e aloestratigrafia para definir o Alosupergrupo Camaquã, que subdividiu nos 
seguintes Alogrupos, separados evidentemente por hiatos deposicionais e suas discordâncias consequentes: Alogrupos Maricá (vulcano-sedimentar, dominantemente marinho, mais de 4000m de espessura), Bom Jardim (vulcano-sedimentar, ambientes lacustres com influência marinha parcial, cerca de 2000m), Cerro do Bugio (vulcano-sedimentar, ambientes lacustres com influência marinha parcial, aproximadamente 500m), Santa Bárbara (siliciclástica, ambientes lacustres com influência marinha parcial, cerca de $2000 \mathrm{~m}$ ) e Guaritas (vulcanosedimentar, condições totalmente continentais, aproximadamente $800 \mathrm{~m}$ ). Descreve uma gradativa diminuição da lâmina d’água no registro sedimentar subaquático, representada por ambientes subaquáticos nunca dissecados (Alogrupo Maricá), passando por ambientes raramente (Alogrupo Bom Jardim) a comumente dissecados (Alogrupos Cerro do Bugio e Santa Bárbara), até condições de frequente exposição aérea (Alogrupo Guaritas). Adaptando o modelo de bacias superpostas para a Bacia do Camaquã proposto por Fragoso-Cesar (1991), afirmam que a Bacia do Camaquã registra uma sobreposição de diversos tipos de bacias. Propõem os seguintes eventos bacinais, da base para o topo: Bacia de Antepaís Maricá, uma bacia tipo strike-slip em ambiente de retroarco referente ao Alogrupo Bom Jardim, duas bacias tipo strike-slip em ambiente de retroarco já em estágio pós-colisional referente aos Alogrupos Cerro do Bugio e Santa Bárbara e, finalmente, um hemi-gráben gerado em condições transtrativas que evoluiu inicialmente associado a um vulcanismo básico a intermediário, em contexto intraplaca, referente ao Alogrupo Guaritas.

Em sua história, realmente, as unidades da bacia passaram por diversos eventos relacionados tanto a regimes tectônicos distensivos, relacionados à gênese dos próprios sistemas de rift da bacia, como compressivos, relacionados a eventos regionais. Estudos mais recentes comprovam, através de análise de proveniência, elementos arquiteturais e análise de paleotensões, que muitas das estruturas que levaram a interpretações de regimes direcionais, são resultantes de eventos pós-deposicionais ( Almeida 2005, Almeida et al. Inédito - anexo 
1, Santos et al. submetido- anexo 2).

Para Almeida (2005), o principal evento deformacional que afetou o Supergrupo Camaquã, posterior à deposição do Grupo Guaritas, é caracterizado por intenso falhamento transcorrente, principalmente falhas sinistrais NE-SW a NNW-SSE e falhas destrais ENEWSW a WNW-ESE, incluindo falhas maiores que justapõem diferentes unidades do Supergrupo Camaquã e seu embasamento. A mineralização em cobre que se encontra no Grupo Santa Bárbara na região das Minas do Camaquã deve estar relacionada a este evento tectônico, uma vez que a mineralização associada às falhas de trend WNW-ESE se comportaram como estruturas distensionais durante este evento, compatível com as fraturas-T do sistema conjugado (Santos et al. Submetido).

\subsection{Grupo Guaritas}

Robertson (1966) denominou Formação Guaritas às rochas localizadas na Serra das Guaritas, a noroeste das Minas do Camaquã. Ribeiro (1970) ressaltou duas fácies nessa unidade: uma fanglomerática e outra subaquática. Observou que, em alguns lugares, a borda leste da unidade está cortada por movimentos recorrentes da falha da Angélica, enquanto que em outros a unidade simplesmente recobre a zona de falha, sem qualquer fraturamento, notadamente na área de Sesmaria do Bonfim. Descreve a fácies conglomerática como áreas restritas de tálus, extensas faixas de fanglomerados com seixos arredondados, arenitos conglomeráticos feldspáticos ou quartzosos com estratificação cruzada de grande porte. Sobre a fácies subaquática, ressalta os arenitos avermelhados feldspáticos ou quartzosos, arenitos conglomeráticos com lentes de conglomerados, siltitos e arenitos finos silto-argilosos e arenitos finos vermelhos. Defende que a deposição da Formação Guaritas ocorreu quando os movimentos referentes às falhas já haviam ultrapassado seu clímax havia muito tempo, ocorrendo apenas pequenas movimentações. Destaca as estruturas NW na Zona de Falhas da Mina do Camaquã em faixa bem definida. 
Tessari \& Giffoni (1970) descrevem a Formação Guaritas como uma sucessão horizontalizada de estratos conglomeráticos e arenosos, arcoseanos. Ressaltam os horizontes sucessivos de arenitos com concentrações de seixos na base, observando uma discordância angular com a Formação Santa Bárbara.

Ribeiro \& Lichtemberg (1978) definiram o Grupo Camaquã como constituído pelo que denominaram Formação Santa Bárbara e Formação Guaritas, seguindo um modelo de bacia molássica deduzido das características similares a tal tipo bacias, apresentando arenitos grosseiros, vermelhos, imaturos e de fácies continental com vulcânicas intercaladas. Ressaltam a diferença de regimes tectônicos que afetaram distintamente cada formação. Observam na Formação Santa Bárbara evidências de uma influência de comportamento compressivo, descrevendo lineamentos de direção NE-SW. Já na deposição da Formação Guaritas, essa tectônica, segundo os autores, deve ter sido amenizada, sendo mais evidente apenas nas regiões de escarpas e flancos bacinais, como indicado pelo tálus basais do que nomeia como Camadas Guarda Velha. Formalizaram dois membros: Camadas Guarda Velha, seção inferior, e Camadas Varzinha, superior. A primeira é constituída por depósitos de detritos rudáceos representados por brechas de tálus e fanglomerados passando lateralmente a arenitos grossos. Já as Camadas Varzinha correspondem a arenitos vermelhos, siltitos e argilitos intercalados em camadas com grande continuidade lateral.

Fragoso-Cesar (1984), Fragoso-Cesar et al. (1984, 1985) e Lavina et al. (1985) consideraram a Formação Guaritas como correspondente à Sequência Superior da Bacia, descrevendo fácies de planície aluvial de canais entrelaçados, deltas lacustrinos e planícies eólicas, depositadas discordantemente à Sequência Inferior, que relacionam ao que denominam de Formação Maricá. Também defenderam o modelo de bacia molássica, relacionando-a ao orógeno do Ciclo Brasiliano.

Fragoso-Cesar (1991) define a Molassa Guaritas como sedimentos molássicos 
continentais de antefossa colocados em grábens, apresentando importantes leques aluviais de clima desértico (ruditos Pedra das Torrinhas e Arenitos Guarda Velha) interdigitados por planícies eólicas (Arenito Pedra Pintada), localmente associadas a pequenos deltas lacustres (Ritmitos Varzinha). Afirma que este sistema de deltas lacustres evoluíram com o tempo, assumindo maior importância nas seções superiores da Molassa Guaritas, sendo que estas sequências deltaicas foram posteriormente assoreadas por sistemas aluviais entrelaçados, sistema esse agrupado pelo autor nos arenitos Guarda Velha. Associa a Molassa Guaritas ao evento Pós-Orogênico Guaritas, que reflete o encerramento das atividades orogênicas Dom Feliciano e Ribeira, e o caracteriza como a estruturação e sedimentação final do Ciclo Brasiliano no Rio Grande do Sul, comum a ambos cinturões orogênicos acima citados. Divide ainda o Grupo em cinco unidades: i) Ruditos Pedra das Torrinhas; ii) Arenitos Guarda Velha; iii) Arenitos Pedra Pintada; iv) Ritmitos Varzinha; v) Andesitos Rodeio Velho. Especificamente sobre os Arenitos Guarda Velha, afirma ser a litologia mais importante da unidade, aparecendo associada vertical e horizontalmente às demais unidades, e caracterizada por arenitos arcoseanos médios a grossos com seixos esparsos, lentes conglomeráticas, seixos bem arredondados, apresentando estratificações cruzada acanalada e por vezes tabular, com participação limitada de conglomerados (notadamente nas proximidades da Serra das Encantadas). Define como área fonte os terrenos metamórficos e terrenos graníticos do Cinturão Dom Feliciano. Relaciona a unidade a desenvolvimento de leques e planícies aluviais entrelaçadas além de deltas. Fragoso Cesar et al. (1999) elevaram a Formação Guaritas à categoria de Grupo.

Trabalhos como Paim et al. (2002), Paim \& Scherer (2003), Scherer et al. (2003) apresentam importantes caracterizações das arquiteturas deposicionais ocorrentes no Grupo Guaritas. Paim et al. (2000) caracterizam o Alogrupo Guaritas como unidade superior do Alosupergrupo Camaquã, com cerca de $800 \mathrm{~m}$ de espessura, apresentando discordância 
angular sobre as unidades mais antigas. Enfatizam o caráter continental desses depósitos e relacionam a esta unidade também o evento ígneo Rodeio Velho. Subdividem este Alogrupo nas seguintes Aloformações: Pedra Pintada (fácies de ambiente desértico e rochas vulcânicas básicas a intermediárias) e Varzinha (fácies aluviais substituídas, seção acima, por uma sucessão deltaica), delimitadas entre si por discordância erosiva. Observa na Aloformação Pedra Pintada depósitos desérticos intercalados próximo à base com vulcânicas básicas (Membro Rodeio Velho), com associações de dunas transversais com fácies interdunares relacionadas à sedimentação eólica, lacustre e aluvial. Na Aloformação Varzinha descrevem condições semi-áridas associadas a um sistema fluvial entrelaçado, porção oeste da Sub-bacia Guaritas, e um sistema de leques aluviais no lado leste daquela sub-bacia. Mais tarde, segundo os autores, este sistema é substituído por uma associação de leques deltaicos tributários no bordo leste da sub-bacia e um sistema de deltas de planície entrelaçada no bordo oeste. Afirmam que esse Alogrupo se depositou em hemi-gráben transtrativo, defendendo uma conexão deste com a fase inicial de instalação da Bacia do Paraná, sobre uma crosta continental já totalmente consolidada. A sucessão aqui estudada é interpretada por Paim (1994) como parte da Aloformação Varzinha, considerando-a portanto como parte das seções superiores da unidade estratigráfica Guaritas, assim como Paim et al. $(1995,2002)$ e Lopes et al. (1999). Paim (1994) caracterizou as rochas da região aqui estudada como depósitos aluviais efêmeros, com base em análise de fácies sedimentares e geometria de camadas.

Almeida (2005) e Almeida et al. (2009) definem o Grupo Guaritas como unidade depositada em sistema de rift cuja área aflorante detém em parte os contornos originais da bacia, que apresentam direção preferencial NNE, com largura em torno de 50km, extensão superior a $150 \mathrm{~km}$ e espessura superior a $1000 \mathrm{~m}$. Salientam que tal grupo ocorre em corpos de direção NNE, limitados tectonicamente entre os altos do embasamento da Serra das Encantadas e de Caçapava do Sul, sendo que tem como embasamento tanto as rochas 
metamórficas e plutônicas brasilianas como as unidades mais velhas da bacia. Afirmam que a unidade apresenta arenitos conglomeráticos, conglomerados, ritmitos psamo-pelíticos e arenitos finos a médios com estratificação cruzada de grande porte, composição predominantemente arcoseana e origem continental. Classificam este grupo como dominado por sistemas fluviais efêmeros, com depósitos de planícies distais e depósitos arenoconglomeráticos de correntes trativas, além de depósitos eólicos. Identificam como autogênicos os ciclos relacionados à migração lateral de sistemas deposicionais e alogênicos os correlacionáveis em escala bacinal e vinculados a superfícies estratigráficas maiores. Os autores dataram intrusão rasa da Suíte Intrusiva Rodeio Velho penecontemporânea ao Grupo Guaritas em 535 Ma, determinando assim uma idade Eocambriana para o Grupo.

O presente trabalho tem como um de seus objetivos o estudo das sucessões fluviais aflorantes na região da Serra das Guaritas, agrupadas na Formação Guarda Velha (prancha 2). Como o escopo do trabalho não é o da revisão estratigráfica, foi adotada aqui a definição proposta por Almeida (2005). Ele reúne na Formação Guarda Velha os arenitos conglomeráticos com estratificação cruzada ou plano-paralela e as lentes de conglomerados da seção inferior do Grupo Guaritas, tendo como seção tipo o Passo da Guarda Velha sensu Ribeiro \& Lichtemberg (1978). Destaca as discordâncias da unidade, angulares sobre o Grupo Santa Bárbara e litológicas sobre o embasamento plutônico e metamórfico. Segundo o autor, seguindo Ribeiro (1970), o contato superior com a Formação Varzinha se dá de forma gradual. 
PRANCHA 02 



\subsection{Grupo Santa Bárbara na Região das Minas do Camaquã}

A revisão bibliográfica sobre essa unidade baseou-se principalmente nos trabalhos de Bettencourt (1972), Silva Filho (1997) e Fambrini (1998) que trataram especificamente das rochas das Minas do Camaquã, onde foram adquiridos a maior parte dos dados estruturais submetidos às análises de paleotensões.

Carvalho (1932) nomeou as rochas da região das minas como "Série Camaquã", embora sem denominar a localidade-tipo. Posteriormente Leinz (1939) adicionou uma nova unidade à série, que descreveu como fortemente inclinada. Em 1961, uma equipe mista de um convênio USGS/DNPM redefiniu a "Série Camaquã" de Carvalho (1932) como Grupo Camaquã, subdividido em Formações Santa Bárbara e Guaritas (Robertson 1966).

Estudando os arenitos e conglomerados relacionados por Robertson (1966) como parte da Formação Santa Bárbara, Ribeiro et al. (1966) agruparam-nos na Formação Arroio dos Nobres, composta pelos membros Mangueirão e Vargas. Ribeiro (1978) incluiu nesse membro Vargas as rochas agrupadas no Grupo Santa Bárbara por Ribeiro et al. (1966). Dividiu ainda os litotipos em 5 níveis, mapeáveis em escala 1:25.000: Arenito Inferior, Conglomerado Inferior, Arenito Intermediário, Conglomerado Superior e Arenito Superior.

Tessari \& Giffoni (1970) descrevem a Zona de Falha Tapera-Emiliano como constituída por dois extensos falhamentos paralelos, separados entre si por uma distância pouco inferior a um $\mathrm{km}$. Para os autores, pelo menos uma dessas falhas se estende para o quadrante NW numa extensão de quase $60 \mathrm{~km}$. A Sul, descrevem uma inflexão para W e posteriormente para NW. Observam que, entre as falhas, ocorrem os sedimentos da Formação Santa Bárbara, sendo que em sua porção setentrional elas afetam as camadas da Formação Guaritas. Consideram a porção setentrional dessa zona de falhas como parte da porção central da Zona de Falhas da Mina do Camaquã. 
Segundo Bettencourt (1972), a Mina Uruguai é dividida pela chamada Falha Piritas em duas zonas: Piritas e Uruguai. Verificou, graças aos trabalhos de lavra na época, a existência de um sistema de veios que ocorrem numa área de $650 \mathrm{~m}$ de largura. $\mathrm{O}$ autor localizou estratigraficamente as rochas da região como pertencentes ao Grupo Bom Jardim, baseado em Ribeiro et al. (1966), e interpretou que estas emergiriam no núcleo de uma anticlinal formada por rochas do Grupo Camaquã e determinariam uma homoclinal cujas camadas possuem direção NE e mergulho médio de cerca de $35^{\circ}$. Interpretou as feições estruturais dominantes como representadas por grandes falhas transcorrentes com direção NE além de falhas associadas normais, tracionais e subisidiárias com direção NW. Descreve que tais estruturas estariam associadas às mineralizações e seriam oblíquas ou transversais à direção média das camadas e à estrutura homoclinal. Observou falhas pós-mineralização cortando as estruturas acima. Os depósitos filonianos teriam se formado, na opinião do autor, por preenchimento e substituição de planos de fraturas e estariam restritos a arenitos, ritmitos e conglomerados dos Membros Vargas e Mangueirão, ressaltando a importância econômica dos depósitos localizados nos conglomerados e arenitos conglomeráticos. Relatou ainda a ocorrência de mineralização disseminada nos espaços entre as falhas. A atitude de tais estruturas mineralizadas teria mergulho para SW na Mina Uruguai e NE na mina São Luís.

O autor observou ainda que a jazida do Camaquã apresenta todas as características de depósitos hidrotermais mesotermais e, com base nos estudos geoquímicos realizados, interpretou que as soluções hidrotermais sulfetadas seriam provenientes de fonte magmática profunda. Os condutos primários seriam as grandes falhas NE que atingiram o embasamento cristalino. Afirma que as soluções teriam sido canalizadas secundariamente para as falhas NW que apresentariam espaços abertos adequados à deposição de sulfetos, óxidos e minerais de ganga.

Sobre a geologia estrutural da área, descreveu as grandes falhas de direção NE, as 
falhas menores subsidiárias (de grande importância econômica), assim como as falhas mais recentes. Especificamente sobre a Mina Uruguai, afirmou que os padrões de falhas principais seriam representados por estruturas N50W-70SW acompanhadas por falhas menores satélites de mesma atitude e mergulho. Observou a presença de juntas oblíquas e paralelas às falhas principais com ângulo de mergulho baixo com valor médio em torno de $37^{\circ}$. Caracterizou as falhas pré-mineralização de atitudes NW-SW e NW-NE, como oblíquas entre si, com ângulos que variam de 30 a $48^{\circ}$. Destacou que os planos de fricção apresentam intensa milonitização e brechamento, com espessuras variando de decímetros a metros. O mergulho das falhas pode variar de 40 a $90^{\circ}$, predominando os planos com mergulhos entre 60 e $80^{\circ}$. Os rejeitos podem atingir algumas dezenas de metros.

Bettencourt (1972) interpretou a maioria das falhas como normais, admitindo a presença de algumas falhas reversas associadas de menor amplitude, admitindo um esforço principal vertical e componente tracional com direção NE/SW com componente compressional médio NW/SE. Relacionou as falhas com direção NE e componente transcorrente destral que ocorrem na região da Mina com o Sistema de Falhas Irapuá, que seria resultante de um esforço regional de primeira ordem. Admitiu que as falhas que interpretou como normais seriam devidas a esforços de segunda ordem com direção predominante NW/SE e sentido SE/NW.

As fraturas de atitude geral NW sinistral, com mergulhos para SW e NE teriam concentrado, segundo Bettencourt \& Damasceno (1974), o minério filoniano sob regime transtrativo ou transpressivo. Descreveram ainda falhas compressivas N a NW interpretadas como secundárias e antitéticas a esse grupo.

Fragoso-Cesar et al. (1985) separaram as rochas da região, baseados na discordância regional apontada por Robertson (1966), em duas formações, a saber: Maricá e Guaritas, separadas entre si por discordância angular e colocadas lado a lado regionalmente por falhas. 
Nesse trabalho, o conceito de Formação Maricá proposto é distinto daquele utilizado por Robertson (1966) e autores posteriores, pois inclui sucessões sotopostas aos sedimentos do Vale do Arroio Santa Bárbara, sendo que estes foram posicionados na Formação Guaritas.

Aplicando na região o conceito de aloestratigrafia, Paim et al. (1992), Paim (1994) e Paim et al. (1995) interpretaram as sucessões da Formação Santa Bárbara como relativas a ambientes aluviais e deltas lacustres. Posteriormente, Paim et al. (2002) separaram tais sucessões em dois alogrupos distintos, incluindo os conglomerados inferiores da unidade no topo do Alogrupo Cerro do Bugio (Aloformação Santa Fé) e as demais unidades (aloformações Serra dos Lanceiros e Pedra do Segredo) no Alogrupo Santa Bárbara.

A Formação Santa Bárbara sensu Robertson (1966) foi elevada à categoria de Grupo por Fambrini (1998) com base em estudos de exposições na Sub-Bacia Camaquã Central (região das Minas do Camaquã), posteriormente expandidos para todas a sub-bacias (Fambrini 2003).

Silva Filho (1997) relatou os lineamentos de direções W-NW, NW, NE e N na região e constatou que as superfícies de acamamento apresentavam na região um basculamento de cerca de $30^{\circ}$ para N-NW e N-NE. Descreveu um padrão anastomosado das fraturas em trends W-NW a NW que interpretou como um sinal de que a região sofreu eventos transcorrentes posteriores aos fraturamentos responsáveis pela formação da bacia. Essa afirmação é sustentada pela observação de que as fraturas das Minas do Camaquã, mais precisamente na Zona Piritas, apresentam estrutura ramificada, com mergulhos tanto para SW quanto para NE com altos mergulhos em maior quantidade do que os de médio mergulho, assemelhando-se em muito a uma estrutura em flor 
negativa. Muitas dessas fraturas são pré-mineralização, sendo preenchidas por fluidos em sua maioria carbonáticos, alguns de quartzo e alguns ricos em sulfetos como calcopirita e bornita.

Silva Filho (1997) separou cinco grupos de falhas na região: 1. trend NW sinistral; 2. trend NW normal; 3. trend W-NW destral; 4. trend W-NW normal; 5. trend N-NE destral, normal e reverso. Apontou para um campo de esforços com compressão E a E-SE e distensão $\mathrm{N}$ a N-NE. Descreve ainda sistemas de falhas de trend NW sinistral compatíveis com conjunto de fraturas sintéticas de Riedell que, segundo ele, dariam origem aos duplexes transcorrentes. Também as fraturas de trend N-NE seriam fraturas secundárias, desta vez sintéticas.

Almeida (2005) afirma que o principal evento pós-deformacional que afetou o Supergrupo Camaquã é caracterizado por intenso falhamento transcorrente, com falhas principalmente sinistrais NE-SW a NNW-SSE e falhas destrais ENE-WSW a WNW-ESE, incluindo falhas maiores que justapõem diferentes unidades do Supergrupo Camaquã e seu embasamento. A mineralização em cobre que se encontra no Grupo Santa Bárbara na região das Minas do Camaquã deveria estar relacionada a este evento tectônico, uma vez que falhas de trend WNW-ESE associadas à mineralização se comportaram como estruturas distensionais durante este evento, compatível com as fraturas-T do sistema conjugado. 


\section{Objetivos}

São os objetivos deste trabalho:

1 - Caracterização da sedimentação da Formação Guarda Velha, base do Grupo Guaritas, através da análise de fácies sedimentares e arquitetura deposicional, com o auxílio de levantamentos estratigráficos e painéis de afloramentos.

2 - Caracterização da tectônica formadora e deformadora do Supergrupo Camaquã, através da análise de paleotensões em estruturas rúpteis encontradas nas Minas do Camaquã, em particular, e em diversas regiões da bacia.

3 - Investigação da origem de estruturas de liquefação comuns na região da Serra das Guaritas através de pesquisa bibliográfica e comparação com exemplos laboratoriais.

4 - Integração das informações em um modelo para o sistema deposicional da Formação Guarda Velha, considerando arquitetura deposicional, influência da tectônica sin-sedimentar e contexto tectônico da bacia. 


\section{Materiais e Métodos}

\subsection{Análise de Elementos Arquiteturais}

A análise de elementos arquiteturais surgiu da necessidade da compreensão em três dimensões de corpos litológicos aluviais limitados entre si por superfícies de terceira a quinta ordem, com características distintivas determinadas por geometria interna, forma externa e, em alguns casos, perfis verticais (Miall, 1985, 1996). Visa, ainda segundo o mesmo autor, a classificação genética e descritiva de litofácies, distinguindo componentes de um sistema deposicional maior ou de igual tamanho de um canal fluvial e, ainda, maior do que uma unidade de fácies. Os depósitos fluviais notadamente se mostraram como uma importante fonte de informação, da qual a análise de afloramentos por meio de painéis e fotomosaicos se mostrou particularmente frutífera, possibilitando o mapeamento 3D que, aliado às comparações com depósitos fluviais atuais, possibilitou um grande avanço no reconhecimento de estilos fluviais. Assim, a análise de elementos arquiteturais tem exercido uma importante contribuição no entendimento de sistemas deposicionais, permitindo o reconhecimento de geometrias e caracterização de processos, preenchendo lacunas as quais a análise de seções verticais não podia por si só preencher.

A unidade fundamental desta análise, chamado strataset, é caracterizada por unidades deposicionais discretas limitadas por superfícies de uma determinada ordem, sendo baseada em termo descritivo e não genético (Miall, 1996). A geometria desta unidade está relacionada com a geometria e migração da forma fluvial associada, sendo que a razão do comprimento pela espessura desses stratasets é similar à razão do comprimento de onda pela altura das formas associadas (Bridge 2006).

O presente trabalho realizou o mapeamento de duas e três dimensões de afloramentos 
escolhidos criteriosamente para a realização de fotomosaicos e levantamento de colunas estratigráficas. Decidida a potencialidade de uma determinada exposição rochosa, seguiu-se a confecção de croquis destacando as principais superfícies-limite, buscando diferenciar possíveis macroformas. Então, foram levantadas seções verticais estratigráficas descrevendo litofácies, dimensões maiores de seixos $(\varnothing \max )$ e paleocorrentes, anotando-se no croqui a posição de cada seção. As técnicas e métodos adotados foram baseados em Miall (1996).

Após a aquisição dos dados, foi realizada a classificação descritiva de Elementos Arquiteturais, baseada nas técnicas de Miall (1996). Esse processo interpretativo baseia-se na interpretação das associações de fácies acima e abaixo das superfícies principais. Leva em consideração: a natureza das superfícies (erosiva, gradacional, irregular, côncava, convexa, etc.); a geometria tridimensional do litossoma (em forma de lençol, lente, corte e preenchimento, etc.); a escala das formas; a litologia através de assembléia de fácies e suas sucessões verticais; a geometria interna; e os padrões principais de paleocorrentes.

\subsubsection{Fotomosaicos}

Foram aqui empregadas algumas técnicas de confecção de fotomosaicos segundo Wizevich (1992), aperfeiçoadas e ajustadas à realidade da fotografia digital. Esta facilita tremendamente a atividade, permitindo a observação em tempo real do produto final e correções que seriam impossíveis na fotografia convencional (película). As fotos foram realizadas em série paralela à direção principal da parede do afloramento, de forma que cada quadro contivesse cerca de $50 \%$ da anterior, configurando uma maior amostragem de pontos na borda do quadro, facilitando a correlação durante as montagens dos mosaicos, além de permitir uma menor distorção da perspectiva; quanto à esta questão, alguns problemas são inevitáveis. Segundo Wizevich (1992), a câmera deve ser posicionada ao longo do plano do acamamento da camada em questão, ou seja, paralelamente à direção de maior mergulho do plano. Porém, isto não é aplicável na prática pela razão de termos inúmeras camadas e seus 
mergulhos de cada camada individualmente apresentarem grande variação de direção em relação aos adjacentes. Seguindo o mesmo autor, foi medida a direção da parede do afloramento por meio de uma bússola para orientação da direção a qual a câmera deveria seguir na sequência de fotos. O espaçamento entre as fotos deveria ser sempre igual, de modo a realizar a amostragem ideal acima descrita.

Realizamos as fotografias visando a construção de um mosaico que englobasse a maior parte possível do afloramento sem que distorções inerentes à fotografia prejudicassem a representação da relação espacial dos litossomas. Cabe notar que a total eliminação deste tipo de erro é inviável e está intrínseca à utilização de fotomosaicos, uma vez que em campo quase nunca encontramos paredes planas e o acesso quase sempre é restrito devido a barreiras naturais, sem falar nas próprias distorções que qualquer fotografia leva inevitavelmente, devido à representação de um objeto 3D em uma superfície 2D.

Para a maior atenuação possível das distorções óticas, a escolha das distâncias focais das lentes foi criteriosa. Muitas vezes os obstáculos naturais exigiram distâncias focais não ideais; diante de tais situações, os croquis foram importantes para a correção das distorções via métodos de tratamento digital de imagens. Levando em conta uma maior resolução ótica, foram escolhidas as aberturas de diafragmas ideais, porém limitados pelas condições de luz.

\subsection{Classificação de Fácies}

Sua aplicação é parte primordial da metodologia no estudo de rochas sedimentares (Miall 1996). Para a classificação de fácies sedimentares foram observados os atributos deposicionais primários (acamamento, granulometria, textura e estruturas sedimentares), segundo as propostas de Reading (1986) e Miall (1977). Este autor propõe uma classificação de litofácies simples, usando um código de duas letras para classificação de estilos fluviais entrelaçados posteriormente expandido para todos os tipos de classes de rios. Aqui foram 
adotados códigos de duas letras, porém sem seguir estritamente esta classificação, mas adaptando ao objeto em questão.

\subsection{Análise de Paleocorrentes}

Provê as informações 3D essenciais para o mapeamento da geometria interna dos corpos sedimentares, podendo nos informar sobre a própria natureza dessas unidades, caracterizando formas como barras, canais e lençóis de areia, bem como diagnosticando a direção de deslocamento dessas formas. A análise de diferentes dados de paleocorrentes relacionados nos painéis fornece importante registro sobre a direção dos mesmos em relação ao corte do afloramento e sobre o grau de variabilidade de direções de paleocorrentes. Os dados reunidos aqui neste trabalho estão relacionados em diagramas tipo roseta.

\subsection{Análise de Paleotensões}

A busca por sistemas conjugados de falhas é uma eficiente ferramenta na análise regional de estruturas rúpteis. Bott (1959), definiu que o deslocamento em um plano ocorre na direção de tensão cisalhante máxima. Conhecendo-se a direção e o sentido de deslocamento em diversas estruturas podemos reconstruir o estado de tensões responsável por tais fraturas. Tal procedimento configura o processo de inversão de dados para análise estrutural de estruturas rúpteis.

O estudo de paleocampos de tensão surgiu na década de 1970, quando pesquisadores perceberam ser possível, através da análise de dados de famílias de falhas com planos estriados e indicadores cinemáticos, a reconstituição dos campos de tensão responsáveis por sua formação. Foram desenvolvidos então métodos gráficos capazes de determinar as orientações dos esforços envolvidos. Dentre esses, destacam-se os de Arthaud (1969) (tensões 
uniaxiais), Angelier \& Mechler (1977), "slip-linear”, "tentativa e erro" (Ramsay e Lislie 2000) e inversão, estes dois últimos numéricos. Todos os métodos partem do princípio que o conjunto de planos pré-existentes tem orientação ao acaso, que as estrias coincidem com a direção de tensão máxima cisalhante no plano, que o deslocamento sofrido foi pequeno e que a tensão foi homogênea sobre a área de estudo.

Angelier \& Mechler (1977) elaboraram o método dos diedros retos (prancha 3i), capaz de reconstituir paleocampos de tensão através da análise gráfica de dados de falhas com estrias em projeção estereográfica, determinando diedros compressivos e distensivos.

Angelier (1994) afirma que podemos chamar um determinado grupo de dados estruturais de um sistema de falhas apenas quando as estruturas são representadas por descontinuidades resultantes de deslizamento numa zona estreita e que se movimentaram sob um mesmo regime tectônico, de forma que seus mecanismos sejam consistentes (prancha 3ii). Esses sistemas devem apresentar ainda atitude e orientação de estrias não contrastantes. A um arranjo geométrico que pode incluir diversos sistemas e ser resultante de diversos eventos tectônicos chama de um padrão de falhas.

A projeção sobreposta de dados de diversas falhas estriadas em diagramas de Schmidt (prancha 4i) proporciona a obtenção gráfica das direções dos campos de esforços nas intersecções dos diedros determinadas por um plano auxiliar ortogonal à estria e ao plano de falha. O sentido do movimento de falha irá indicar a natureza compressiva ou distensiva de cada campo.

Segundo Delvaux \& Sperner (2003), poderemos reconstruir os eixos de paleotensões responsáveis por um sistema de falhas se este apresentar no mínimo duas famílias de falhas, sets de estrias perpendiculares à direção de intersecção da falha e pares rotacionais causados pelos dois movimentos de falhas com movimento oposto de forma a ocorrer encurtamento no ângulo agudo entre as falhas. $O$ ângulo entre as falhas deve ser consistente com as 
propriedades mecânicas da rocha na época do falhamento. Para os autores, a análise de esforços deve considerar certo volume de rocha grande o suficiente para abrigar um conjunto de dados estruturais com diferentes superfícies de cisalhamento. Para tal análise, o volume rochoso analisado deve ser muito maior que a dimensão das estruturas rúpteis individuais. Afirmam também que o sentido e direção de deslocamento são deduzidos através da análise de estrias tipo slickenlines. Reúne-se assim um conjunto de dados contendo strike e dip da falha, a orientação da estria e a cinemática dos blocos. A inversão de tais dados fornecerá as relações entre os campos de tensão principais: $\sigma 1$ (tensão máxima), $\sigma 2$ (tensão intermediária), $\sigma 3$ (tensão mínima) bem como a Razão de Tensão $\mathrm{R}=(\sigma 2-\sigma 3) /(\sigma 1-\sigma 3)$. Através de tais dados, podemos inferir os campos de tensão responsáveis por determinadas estruturas através da modelagem dos possíveis deslocamentos em cada plano de falha. O campo de tensão atuante durante determinado evento de deformação será único e será ativo apenas nesse determinado momento, sendo que logo após esse uma vasta gama de tensores pode induzir movimentação por reativação. Diversas definições da razão de esforços são encontradas na literatura (e.g. Bott 1959, Carey-Gailhardis \& Mercier 1987, Angelier 1994).

A reativação de planos de fraqueza são consideradas como falhas. Tais planos podem ser herdados de antigas estruturas, antigas juntas ou ainda planos relacionados a estruturas sedimentares primárias. As direções do deslocamento no plano de fraqueza dependem da orientação dos três principais eixos de tensão, da razão de tensão $\mathrm{R}$ e da orientação da normal ao plano. A relação entre os componentes de tensão normal e cisalhante determina a 
PRANCHA 03 
PRANCHA 04 
habilidade de um plano em ser reativado e é expressa pelo coeficiente de fricção $\theta$.

Para a análise de estruturas em seu programa TENSOR, Delvaux \& Sperner (2003) consideram como falhas apenas os planos com estrias mensuráveis e com indicação cinemática, englobando todos os outros tipos de planos rúpteis como fraturas. De forma a relacionar os planos rúpteis com os eixos de tensão, classifica geneticamente aqueles como fraturas de tensão (juntas de tensão) ou fraturas de cisalhamento, afirmando que ambas podem aparecer como pares conjugados. Fraturas de compressão formam um conjunto particular que também pode ser analisado pelo programa. Se houver a certeza de que nenhuma deformação ocorreu ao longo de um plano de clivagem por dissolução, podemos considerar este como uma fratura de compressão. Indicações de relações temporais entre estrias e falhas são muito importantes para qualidade dos dados, bem como uma avaliação da confiabilidade de cada dado.

\subsubsection{Métodos de Campo}

Neste trabalho, para a determinação do sentido do movimento das falhas em campo, observamos: se havia ou não separação estratigráfica, se eram reconhecíveis estrias nos planos de falhas, se estes apresentavam ou não preenchimento mineral e se havia alguma relação entre este preenchimento e as estrias em curvaturas e inflexões no plano de falha. Os critérios de Petit (1987), Angelier (1994) e Doblas (1998) determinam o sentido do movimento das falhas. A cinemática das estrias foi interpretada segundo os métodos expostos por Angelier (1994), apresentados na prancha 4ii.

\subsubsection{Métodos de análise estrutural e correlação cronológica}

Aplicamos a metodologia de inversão de dados estruturais rúpteis para a distinção de diferentes campos de tensão bem como sua inter-relação cronológica. Utilizando o programa de tratamento de dados estruturais e análise de paleotensão TENSOR (Delvaux \& Sperner 
2003), este trabalho busca contribuir com a correta correlação cronológica dos eventos tectônicos que estiveram ativos e deformaram a Bacia do Camaquã. Para correlação regional foram utilizados dados de sensoriamento remoto.

A análise seguiu uma metodologia segundo a qual os dados foram primeiramente plotados em estereogramas, analisados quanto aos possíveis campos geradores de tais estruturas que foram então inseridos no aplicativo de optimização rotacional, no qual se separou as estruturas conjugadas, ativadas, não ativadas e incompatíveis. Foram descartados todos os dados cujo ângulo entre a estria real e a estria esperada para cada plano apresentava desvio de mais de $30^{\circ}$. Numa segunda etapa, apenas as estruturas conjugadas e ativadas foram submetidas a nova rotação para uma melhor adaptação do campo hipotético de tensão. Foram então gerados diagramas em projeção estereográfica com as falhas, estrias e campo de tensão obtido para cada família. Apenas famílias com um mínimo de quatro dados de falhas com estrias foram aceitas para a determinação de paleocampos de tensão. As idades interpretadas para cada evento foram baseadas nas datações obtidas por diferentes métodos em diferentes trabalhos na Bacia do Camaquã e em considerações sobre as relações de corte entre estrias em um mesmo plano.

\subsection{Estudo de estruturas de liquefação}

Um dos objetivos iniciais deste trabalho foi o estudo de caso das abundantes estruturas de liquefação encontradas nos afloramentos abordados. Num primeiro momento, procurou-se investigar a possibilidade destas estruturas serem utilizadas como superfícies de correlação entre afloramentos. Porém, foi observado que estas estruturas ocorrem em quase todos os níveis, com ocorrências e características diversas. Isso não significou o abandono deste estudo e assim, através de pesquisas bibliográficas, pudemos atribuir boa parte destas estruturas a 
eventos sísmicos que podem informar sobre a atividade tectônica atuante durante a deposição dos corpos areníticos aqui estudados, bem como sua ciclicidade.

Rust (1968) descreve sucessões de quartzo-arenitos de granulação fina bem selecionados, apresentando estratificações cruzadas deformadas em dobras recumbentes com eixos de deformação perpendiculares ao mergulho das estratificações não-deformadas, apresentando transição gradual de estruturas deformadas para não deformadas em ambas direções, à montante e à jusante da paleocorrente. São rochas de idade Cretácea a Terciária sobrepostas diretamente ao embasamento gnáissico pré-cambriano na Ilha Somerset, Ártico do Canadá. Quando não deformadas, as estratificações são em sua maioria planares, com espessura de sets variando de alguns centímetros a pouco mais de um metro, com algumas séries acanaladas. Já as deformadas, cerca de dez por cento, aparecem entre sucessões não deformadas acima e abaixo e, ainda, tal deformação diminui a juzante e montante da direção de paleocorrente. A deformação é descrita como regular, com foresets de ângulo normal $\left(15^{\circ}\right.$ a $20^{\circ}$ ) que gradualmente tornam-se mais íngremes, assumindo finalmente uma forma de dobra recumbente. Foi observada deformação abrangente em sets delgados enquanto que em sets espessos esta aparece concentrada na porção superior daqueles. A gradação de sessões deformadas para não deformadas sugerem, segundo o autor, uma deformação concomitante à deposição destas sucessões. Duas importantes conclusões levantadas pelo autor: 1) a recumbência das dobras em direção paralela à direção de fluxo revela uma inter-relação entre a deformação e a direção de corrente; 2) ocorrência de massas lenticulares de arenitos maciços situados imediatamente acima das porções deformadas de cada set. $\mathrm{O}$ autor sugere que as deformações seriam ocasionadas por arrasto de massa de sedimentos movimentados por corrente, com base na deformação regular e orientação dos eixos das dobras em direção perpendicular à direção de corrente e na passagem regular, em direção paralela ao paleo-fluxo de sets não deformados para sets deformados, passando novamente para não deformados. 
Segundo Owen (1996), ocorrem dois mecanismos de deformação em areias inconsolidadas e saturadas por água: Liquefação e Fluidificação. A Liquefação é definida como a perda temporária de força de consolidação consequentemente da desestruturação da trama de grãos e transferência da sustentação destes para a pressão de fluidos, que sofre incremento em consequência de abalos sísmicos, passagem de ondas, movimentos do lençol freático ou impactos e não requerendo mudanças de volume nem influxo de fluidos. Uma vez atingido o estado de liquefação, o sedimento sofre deformação com geometria determinada pelas forças atuantes nos sedimentos. Por sua vez, a fluidificação é descrita como um fenômeno no qual o fluido intersticial flui em direção ascendente através da trama de grãos numa taxa tão alta que o arrasto ocasionado pela movimentação do fluido iguala ou excede o peso das partículas. Dessa forma, a fluidificação requer uma fonte externa de fluidos.

Para Allen (1984), liquefação caracteriza os mecanismos envolvidos na mudança de estado tipo sólido para tipo líquido em depósitos inconsolidados que perdem então resistência e passam a se comportar como fluidos viscosos. Com esta perda de estruturação, os grãos passam a não mais se suportar mutuamente, ficando temporariamente dispersos no fluido. $\mathrm{O}$ autor afirma que, na natureza, a causa mais comum para tal fenômeno é a ocorrência de terremotos. Descreve três tipos diferentes de liquefação: estática, dinâmica e cíclica. A liquefação estática ocorre quando o material incoeso, através de um aumento suficiente da pressão de fluidos perde a resistência ao cisalhamento, e se deforma. Um exemplo equivalente seria uma camada arenosa sotoposta a uma impermeável, com consequente aumento de pressão hidrostática e diminuição da resistência ao cisalhamento. A liquefação dinâmica relaciona-se a uma deformação ocasionada pela aplicação de impulso ou carga a uma massa. Liquefação cíclica resulta da ação repetida de carga reversa, como num terremoto ou passagem de série de ondas.

Ainda segundo Allen (1984), ondas de cisalhamento induzidas por abalos sísmicos em 
camadas de areia e silte grosso inconsolidados submetem o material a repetidos tremores horizontais. Estas tensões cisalhantes reversas são submetidas temporariamente à tensão normal constante controlada pela espessura do soterramento sedimentar e coluna hidrostática equivalente. Como a frequência, amplitude e duração do tremor variam com a magnitude do abalo sísmico, distância do epicentro e as características e espessura das camadas pelas quais as ondas de choque viajaram e, ainda, a liquefação cíclica associada a terremotos é principalmente associada àqueles de magnitude 6 ou maior, o autor conclui que o fenômeno apresenta dados com importância de caráter regional. Cita que, dadas circunstâncias favoráveis, a liquefação cíclica pode ocorrer simultaneamente em depósitos inconsolidados sobre áreas com centenas a milhares de quilômetros quadrados. Frisando novamente, para este autor, na liquefação o fluido é essencialmente passivo.

Na fluidificação, ainda segundo Allen (1984), o fluido é agente principal, provendo com seu movimento ascendente a força que sustenta o peso das partículas após a expansão de acamamento, passado o estágio no qual o contato inter-granular pode existir. Descreve dois tipos de fluidificação: estacionária e translacional. Na primeira, não ocorre movimento horizontal nem vertical do centro de gravidade da massa fluidificada, apesar do não impedimento de movimentos internos das partículas envolvidas. Na translacional, ocorre movimento horizontal de partículas. Quando o movimento dos grãos se dá sobre uma camada inclinada no sentido do mergulho, denomina fluidificação de fluxo. Refere-se ao tipo de fluidificação onde as partículas são suportadas pelo fluxo interno ascendente produzida pela frente da massa em movimento, semelhante a correntes de turbidez, como auto-fluidificação.

Allen (1984) define estruturas de deformação de sedimentos inconsolidados como aquelas que apresentam evidências de formação durante o processo de deposição ou logo após o início do soterramento. Nesse intervalo de tempo, a água contida nos poros desses sedimentos é gradualmente expelida. Quando esse processo é interrompido, pode ocorrer 
acentuação abrupta do mesmo, levando pesquisadores como Lowe (1975) a classificarem a maioria de estruturas de deformação sin-sedimentares como estruturas de escape de água. Para Allen (1984), o fluido é geralmente causa e consequência direta da deformação, observando que a maioria das estruturas prevalecem em sedimentos subaquosos e aparecem, importante notar aqui, mais frequentemente onde altas taxas de sedimentação prevalecem, promovendo empacotamento frouxo de areias e siltes, como em sedimentos afetados por correntes de turbidez, ambientes marinhos rasos influenciados por tempestades, deltas e planícies de inundação fluvial. Classifica estruturas de deformação de sedimentos inconsolidados em três tipos: pós-deposicionais, meta-deposicionais e sin-deposicionais. Descreve como dobras caracteristicamente acentuadas em direção ao topo da camada, partindo de base não deformada, sem evidência de superfícies de descolamento e que podem ser truncadas no topo. Distingue estruturas de deformações relacionadas a perfis verticais gravitacionalmente instáveis, que chama de laminações convolutas e apresentam segundo o mesmo autor forma predominante de dobras em domos e bacias, devido às forças de deformação primárias essencialmente verticais. Deformação relacionadas a componente de transporte para jusante (estratificações cruzadas deformadas) são caracterizadas por uma combinação de dobras e falhas com distúrbio local ou destruição das laminações. As características descritas são as seguintes: pequenas dobras variando entre desarmônicas a verticalizadas, passando por dobras de arrasto a formas semelhantes a nappes; falhas normais com rejeito em direção ao mergulho do foreset e ocasionalmente pequenas falhas reversas; pedaços de sedimentos vagamente laminados a aparentemente sem estruturas.

Caracterizando estratificações cruzadas recumbentes como relacionadas a arrasto de fluido, Allen (1984) classifica-as como cruzadas deformadas simples. Podem formar dobras recumbentes ou ainda dobras menores desarmônicas na zona de charneira ocorrendo também casos de dobras pequenas com crescente amplitude em direção ao topo do set. A maioria dos 
exemplos citados referem-se a depósitos fluviais, com raros casos em rochas de origem lacustre, deltaica ou marinha. As charneiras são fraca a moderadamente curvadas na direção de fluxo, confinadas a sets individuais e truncadas no topo por camada erosiva não deformada. Podem persistir em distâncias de 10 a 20 vezes a espessura do set, sumindo a montante e jusante do fluxo. Importante notar que, nas estruturas descritas, os eixos das dobras são em média perpendiculares ao azimute do mergulho dos sets não deformados. Como apresentam translação horizontal, pode-se afirmar que foram afetadas por força de cisalhamento simples, estavam saturados em água e que, no momento da deformação, estavam liquefeitos, devido à ausência de falhas e dos frequentes flancos superiores extensos.

Allen (1984) defende que tais deformações são decorrentes de arrasto cisalhante de corrente sobre a superfície da camada deformada, corroborados pela persistência lateral, forma similar, orientação com a paleocorrente e natureza recumbente. A natureza do fluido cisalhante, por outro lado, é controversa. Allen \& Banks (1972) defendem que tais dobras são resultado de arrasto por corrente ou maré, assumindo-se que o sedimento estivesse liquefeito.

Røe \& Hemansen (2006) defendem, por sua vez, que as estratificações cruzadas deformadas teriam uma origem autocinética, sem a influência de abalos sísmicos, com base na ausência desses tipos de estruturas em rochas marinhas e pela variação lateral da deformação, passando em questão de metros de porções deformadas para não deformadas. Estudando arenitos fluviais expostos na Noruega que exibem estratos cruzados tabulares, que por sua vez apresentam sets deformados em dobras recumbentes associadas a arenitos maciços, salientaram a diminuição gradual da deformação tanto a montante quanto a jusante da direção de fluxo. Estas porções mais deformadas apresentam formas de cunhas com mergulho corrente abaixo, sotopostas a superfícies de reativação. Devido à deformação localizada, seja horizontalmente ou verticalmente, em ocorrência alternada, atribuem sua origem autocinética. Sugerem que este tipo de estrutura é de pequena serventia para estudos paleotectônicos a 
menos que uma evidência independente de uma origem alocinética possa ser identificada.

Por outro lado, Owen (1996) descreve as seguintes estruturas geradas em laboratório através de liquefação ativada por mesa vibratória simulando sismos em experiências de flumes, e comprovando a origem alocinética para essas estruturas:

1. Estruturas derivadas de colapso de encostas: estratificações inclinadas e retorcidas, com foresets deformados em um par de dobras recumbentes compreendendo uma sinforma inferior e uma antiforma superior. Zonas contorcidas formam-se em resposta ao cisalhamento ocasionado no interior do corpo de areia, entre a areia e a base do tanque, como no caso das cruzadas recumbentes descritas por Rust (1968). A parte superior do corpo de areia é submetida a um cisalhamento puro enquanto que a zona de cisalhamento é submetida a cisalhamento simples, com a estratificação originalmente inclinada se tornando íngreme e dobrada. Onde os sets da base com baixo mergulho foram comprimidos entre o corpo de areia em expansão e o limite da parede do tanque, aqueles foram deformados assumindo formas de dobras inclinadas com superfícies axiais mergulhando em direção ao corpo de areia.

2. Deformação ocasionada por sobrecarga desigual de superfície: ocasionou uma laminação que se tornou mais achatada e plana na parte superior e na parte inferior se tornou mais contorcida. Onde a encosta da parte elevada mergulhava na mesma direção dos foresets no substrato, estes se deformaram em pares dobras sinclinal-anticlinal com o mesmo senso de pares de cisalhamento como descritos nos colapsos de encostas. Quando a encosta e o substrato apresentaram direções opostas de mergulho, o senso de pares de cisalhamento era reverso em relação ao mergulho do foreset, originando estratificações cruzadas com maior mergulho.

3. Deformação ocasionada por gradientes de densidade gravitacionalmente instáveis: muito semelhantes a muitos casos encontrados na Serra das Guaritas, este caso compreende 
PRANCHA 05 

PRANCHA 06 

estruturas de sobrecarga em sistemas de areia sujeitos à liquefação. Estes sistemas apresentam diferenças de densidades ocasionadas em função de processos deposicionas e formato, seleção e tamanho de grão. Foram geradas dobras menores que se desenvolveram em contrastes granulométricos entre laminações graduadas que se formaram durante a deposição de areia mais fina. Algumas dessas dobras menores apareceram como cúspides de escape de fluidos, sugerindo que fluidificação ocorreu localmente dentro da camada inferior e que aquela deformação ocasionada por escape de fluidos foi sobreposta à deformação ocasionada pelo gradiente de densidade gravitacionalmente instável (prancha 5B). Como exemplo na área investigada temos a prancha 5D, encontrada no painel 1.

4. Deformação ocasionada por cisalhamento tangencial: o autor agrupa aqui as estratificações cruzadas recumbentes. Neste caso a liquefação foi gerada ao mesmo tempo em que a corrente de flume fluía. Os foresets foram deformados em sinclinais recumbentes, ocupando toda a espessura do set e com passagem lateral dos foresets não deformados ocorrendo abruptamente (prancha 5B), como encontrado no painel 6 e na prancha 5B superior e 6D, esta última gerada em laboratório após submetida a liquefação gerada por sismo. O exemplo da prancha 6A é interpretado como gerado a partir desse tipo de fenômeno e encontrado em seções do Jurássico Superior da Grã-Bretanha.

5. Deformação ocasionada por cisalhamento vertical: agrupa aqui as estruturas de fluidificação associadas a estruturas de liquefação geradas por sismo ou a movimentos do lençol freático. Apresentam tipicamente cúspides ou pilares, estruturas em pires, diques clásticos e vulcões de areia. A deformação ocorre o movimento da água intra-poro é impedido tanto por uma camada de baixa permeabilidade quanto por uma camada de sedimento que é menos facilmente fluidizada. As prancha 5C (localizada no painel 3), 6B e 6C representam exemplos encontrado no painel 1 enquanto que a prancha 5A representa um exemplo desse tipo de estrutura gerado em laboratório. 


\section{Resultados}

Foram realizados o levantamento de 42 seções estratigráficas totalizando $420 \mathrm{~m}$, a identificação e interpretação de fácies sedimentares, a confecção de modelos idealizados do preenchimento sedimentar interpretado, 11 painéis com interpretação de elementos arquiteturais totalizando $1.117 \mathrm{~m}^{2}$ mapeados por essa técnica, a medição de 144 dados de paleocorrentes e 102 dados pareados de falhas com estrias e indicadores cinemáticos. Figuras retiradas da literatura foram modificadas, submetidas às mesmas técnicas aqui usadas para salientar estruturas de interesse, através da colocação do desenho interpretativo colocado lado a lado das fotografias (pranchas 5 e 6 ).

As fácies predominantes (prancha 7A) encontradas são de arenitos grossos a conglomeráticos com estratificação cruzada acanalada (44\%), seguidos de arenitos médios a grossos laminados $(23 \%)$, arenitos conglomeráticos em estruturas de corte e preenchimento (18\%), conglomerados clasto-suportados de seixos imbricados (13\%) e, por fim e em menor frequência, pelitos localmente gretados e arenitos finos a médios com climbing-ripples. O diâmetro máximo dos clastos é (prancha 7B) predominante de cerca de $4 \mathrm{~cm}$, podendo chegar até a $32 \mathrm{~cm}$ na base da unidade estratigráfica. As superfícies limitantes de elementos arquiteturais são predominantemente de caráter erosivo. A análise de paleocorrentes mostra um transporte predominante para WSW (prancha 7C). Foram agrupadas separadamente as espessuras dos sets de estratificações cruzadas acanaladas (prancha 7D), que ficam em média entre 10 e $80 \mathrm{~cm}$. 
PRANCHA 07 



\subsection{Fácies Sedimentares}

As rochas da Formação Guarda Velha são caracterizadas por arenitos arcoseanos e arenitos conglomeráticos de baixa maturidade mineralógica, com seixos arredondados de proveniência principal constituída por riolitos, sienogranitos, quartzo milonito e quartzo de veio. Conglomerados clasto-suportados ocorrem com grande frequência na base da Formação Guarda Velha, porém desaparecem em direção ao topo. De Ros et al. (1994) destacam a cimentação carbonática eodiagenética como corroboradores desta afirmação.

Al - arenitos finos a grossos com estratificação plano paralela, laminados (prancha 8A), de espessuras decimétricas a pouco mais de um metro apresentando comumente lineação primária de corrente que revela intensa variação de direção de paleocorrentes. Equivale à fácies Sh de Miall (1996). Interpretados como depósitos gerados por deposição em leitos planos em regime de fluxo superior ou próximo à velocidade crítica, em canais desconfinados.

Aa - arenitos médios a grossos, por vezes conglomeráticos, com estratificação cruzada acanalada de médio a grande porte, de dimensões decimétricas a pouco mais de um metro (prancha 8B). Os seixos aparecem esparsos ou concentrados na base dos sets. Equivale à fácies St de Miall (1996), interpretados como depósitos de dunas subaquáticas 3D linguóides e de crista sinuosa, geradas por regime de fluxo inferior. Podem apresentar concentrações de seixos na base dos sets (prancha $8 \mathrm{C}$ ).

PI - pelitos laminados que ocorrem em camadas decimétricas (pranchas 8D), localmente intercaladas à fácies Alc (prancha 8E). Podem aparecer sobrepostos a superfícies erosivas. A laminação acompanha, em alguns exemplos, a forma da superfície basal podendo assumir 
característica de drape em dobras suaves onde a laminação é concordante com a superfície basal. Interpretados como depósitos de abandono de canal.

Alc - arenitos finos a médios com laminação cruzada cavalgante (climbing ripples, prancha 8F) que ocorrem em camadas centimétricas associadas às fácies $\mathrm{Pl}$, sotopostas ou em variação lateral. Interpretados como depósitos decorrentes da perda de força trativa de corrente, com deposição simultânea por tração e suspensão. Equivale à fácies Sr de Miall (1996).

Pg - pelitos com gretas de contração em estratos centimétricos e de extensão lateral métrica limitada ora pela fácies Alc ora pela fácies Acp, podendo também ocorrer intercalados a essas mesmas (prancha 8G). Localmente aparecem gretas poligonais variando de espessuras milimétricas a centimétricas. Representam eventos de abandono de canais seguidos por decantação, exposição sub-aérea e gretação. São encontradas gretas de cerca de $10 \mathrm{~cm}$ com fendas preenchidas por arenito grosseiro.

Acp - arenitos médios a grossos, frequentemente conglomeráticos e com intraclastos, em estruturas de corte e preenchimento (scours) de extensão lateral e vertical decimétrica a métrica, por vezes com estratificação cruzada concordante com a superfície erosiva basal (prancha 8H). Equivale à fácies Ss de Miall (1996). Indicam eventos de rápida deposição de material pouco selecionado em regime de fluxo inferior, em correntes trativas em sistemas de rios entrelaçados efêmeros.

Aagn - arenitos conglomeráticos com estratificação acanalada de médio a grande porte, 
PRANCHA 08 

PRANCHA 09 

com gradação normal (prancha 9B). Interpretados como pequenos deltas de Gilbert, com deposição por correntes de densidade nos foresets de uma barra que avança em corpo d'água estagnada. Essa fácies é rara e de ocorrência isolada.

Ci - conglomerados polimíticos de seixos arredondados, imbricados paralelamente ao eixo médio, estratificação incipiente (prancha 9A). Equivale ao Gh de Miall (1996), interpretados como depósitos de formas de leito conglomeráticas longitudinais associadas a canais entrelaçados. Esta fácies ocorre predominantemente na base da Formação Guarda Velha, representada aqui pelas exposições do Rincão da Guarda Velha (onde se concentra predominantemente na base da seção) e Passo do Cação. Estratigraficamente acima, deixa de ocorrer.

As - arenitos médios com estratificação sigmoidal (Prancha 9C). Interpretados como depósitos de transição de regime de fluxo inferior para o superior, semelhantes às humpback dunes descritas por Fielding (2006). Essa fácies é relativamente rara.

Ac - arenitos finos a conglomeráticos convolutos apresentando dobras desarmônicas comumente truncadas por superfícies erosivas (Prancha 9D a 9H). Representam as fácies Al, Aa e Acp de Mial (1996) submetidas a fenômenos de liquefação desencadeados pela ação por vezes conjunta de sismos e tração de corrente. Ocorrem estruturas de fluidificação associadas.

\subsection{Elementos Arquiteturais}

$\underline{\mathbf{F C}}$ - formas de leito conglomeráticas, em camadas centimétricas a métricas de fácies Ci equivalentes ao elemento GB de Miall (1996). Ocorrem na porção mais basal da Formação Guarda Velha, aqui representada pelos afloramentos do Rincão da Guarda Velha e do Passo do 
Cação, onde podem apresentar diâmetro máximo de clasto de até $32 \mathrm{~cm}$. São interpretados como formas de leito de carga trativa em sistemas fluviais entrelaçados, formadas durante eventos episódicos de grande vazão de água e adição a jusante de lençóis cascalhosos em barras longitudinais e transversais.

$\underline{\mathbf{F A}}$ - formas de leito arenosas, em camadas decimétricas a métricas, base plana (em escala de afloramento), lateralmente contínuas, apresentando a fácies Aa em forma de campos de dunas 3D, com estratificações de médio a grande porte. Equivalentes ao elemento SB de Miall (1996), interpretado como campos de dunas de fundo de canal.

$\underline{\mathbf{L A}}$ - lençóis de arenitos laminados, equivalentes ao elemento LS de Miall (1996), tabulares, em camadas decimétricas a métricas de fácies $\mathrm{Al}$, com superfície basal planar e erosiva. Apresentam frequentemente lineação primária de corrente com grande variação na direção de paleocorrentes (prancha 10A), interpretado como fruto de fluxo desconfinado em regime de fluxo superior decorrente de perda de vazão de eventos episódicos.

$\underline{\mathbf{A J}}$ - macroformas de acresção à jusante, produto da acresção em barras longitudinais. Caracteriza-se por estratificação cruzada composta, com séries de cruzadas separadas por superfícies que mergulham para o mesmo sentido das estratificações acanaladas da fácies Aa, porém com menor inclinação. Revelam a existência de barras ativas relativamente perenes, com deposição persistindo por períodos maiores que um única enchente em sistemas de rios entrelaçados. Correspondem ao elemento DA de Miall (1996). Este elemento é de ocorrência muito restrita na unidade investigada. 
PRANCHA 10 

$\underline{\mathbf{C P}}$ - estruturas de corte e preenchimento, representados por corpos lenticulares de poucos metros de extensão e espessura. O preenchimento é dado pelas fácies $\mathrm{Aa}$ ou $\mathrm{Al}$, cortando erosivamente o topo dos elementos FA, LA ou PE. É comum a concentração de seixos na área frontal do set, na área de incisão mais profunda. A deposição é posterior ao escavamento, podendo apresentar intraclastos (prancha 10B).

$\underline{\mathbf{E A}}$ - escavações abandonadas. Corpos em forma de canal, côncava para cima com laminação acompanhando o fundo da superfície inferior, em drape, com espessuras centimétricas a métricas e extensão lateral de alguns metros. Esta superfície inferior pode truncar erosivamente o elementos CE (prancha 10C).

$\underline{\mathbf{P I}}$ - planícies de inundação, equivalente ao elemento OF de Miall (1996). Sua relação com o elemento CE é exemplificada no painel 1 e desenho interpretativo. Referem-se a áreas adjacentes a canais principais que são por hora alagadas e posteriormente abandonadas, prevalecendo então deposição por decantação, com intercalações restritas das fácies Aa e Alc. Suas dimensões não passam de algumas dezenas de metros verticalmente e alguns poucos metros lateralmente. Podem apresentar gretas. Esses depósitos são interpretados como decantação adjacente a um canal sujeitos às variações de nível d'água.

\subsection{Descrição dos afloramentos e fotomosaicos mais relevantes.}

\section{Painéis 1 e 2}

Localização: UTM 22J 259278/6586290

Predomínio de fácies Aa (51\%), com importante participação de Al (26\%) e Acp 
(22\%) e ocorrência limitada $(1 \%)$ porém significante de $\mathrm{Pg}$. O elemento arquitetural predominante é o FA, aparecendo subordinadamente os elementos LA e PI. As superfícies erosivas são predominantemente côncavas para cima. Aparecem gretas (prancha 17A) com alguns centímetros de espessura sotopostas a forma de leito arenosa de cerca de dois metros de espessura que preenchem os interstícios entre as gretas. Essas gretas acompanham a superfície da forma de leito abaixo, assumindo leve basculamento. Lateralmente à região de principal escavação do canal, representado pelo elemento FA, lateralmente também às gretas citadas, temos uma camada centimétrica de pelito com gretas curvadas (curled flakes, prancha 8G). A relação da estrutura de escavação com o estrato gretado é interpretada na prancha 11 e relacionada a planície de inundação em região lateral à bancada principal de um canal entrelaçado. Foram encontrados climbing-ripples na região mais profunda desta escavação, porém numa parte da parede alterada de tal forma que não possibilitou o levantamento de coluna estratigráfica com o nível de detalhe aqui abordado. As paleocorrentes predominam para WSW. Ocorrem diversas estruturas de liquefação relacionadas a atividades sísmicas ( sismitos). Ømax $=10 \mathrm{~cm}$. Lateralmente, no mesmo morrote, a cerca de trinta metros de distância do painel 1, foi realizado o painel 2, com predomínio de superfícies erosivas planares e intercalação dos elementos LA e FA, com direção contrastante de paleocorrentes em relação ao primeiro. As colunas estratigráficas apontadas nos painéis são apresentadas nas pranchas $12 i$ e $12 i i$.

\section{$\underline{\text { Painel } 3}$}

Localização: UTM 22J 259273/6585487

Predomínio de fácies Aa (48\%), subordinadamente Al (25\%) e Acp (23\%); restrito a um nível, $\mathrm{Pg}(3 \%)$. O elemento arquitetural predominante é o FA, ocorrendo um elemento CP 
Painel 1 

